\title{
CHALLENGES OF OBSTETRIC ANESTHESIA: DIFFICULT LARYNGEAL VISUALIZATION
}

\author{
Zekeriyya Alanoğlu, Süheyla Karadağ Erkoç, Çiğgdem Yıldırım Güçlü, Başak Ceyda Orbey Meço, \\ Volkan Baytaş, Özlem Selvi Can and Neslihan Alkış
}

Department of Anesthesiology and ICM, School of Medicine, University of Ankara, Ankara, Turkey

\begin{abstract}
SUMMARY - Obstetric anesthesia is one of the high risk subspecialties of anesthesia practice. Anesthesia related complications are the sixth leading cause of maternal mortality. Difficult or failed intubation following induction of general anesthesia for CS remains the major contributory factor to anesthesia-related maternal complications. The airway management of obstetric patients is a challenging issue for several reasons. Anatomic and physiologic changes related to pregnancy may increase the difficult and failed intubation rates compared to the general surgical population. Proper evaluation of the airway anatomy and airway structures is vital to prevent airway management related catastrophes. In addition to basic airway and intubation equipment, each anesthesia department must have difficult intubation equipment cart including fiber optic laryngoscope, video laryngoscopes, and different types of laryngeal masks. It is essential that all anesthesiologists have a preconceived and well thought-out algorithm and emergency airway equipment to deal with airway emergencies during difficult or failed intubation of a parturient.
\end{abstract}

Key words: Anesthesia, General; Anesthesia, Obstetrical; Airway Management; Airway Obstruction; Intubation, Intratracheal

\section{Introduction}

Obstetric anesthesia is one of the high risk subspecialties of anesthesia practice. Most of the deliveries take place without the need of anesthesia but when anesthesia is required due to anatomic and physiologic changes related to pregnancy, it may increase the risks of mortality and morbidity. Anesthesia related complications are the sixth leading cause of maternal mortality in the USA ${ }^{1}$. Difficult or failed intubation following induction of general anesthesia for cesarean section (CS) remains the major contributory factor to anesthesia-related maternal complications ${ }^{1-4}$.

The airway management of obstetric patients is a challenging issue for several reasons. Anatomic and

Correspondence to: Prof. Zekeriyya Alanoglu, MD, DESA, Department of Anesthesiology and ICM, School of Medicine, University of Ankara, Ibn-i Sina Hastanesi 3.Kat D.Blok Samanpazari, 06100 Ankara, Turkey

E-mail: zekeriyya_69@yahoo.com

Received March 5, 2015, accepted: October 24, 2015 physiologic changes related to pregnancy may increase the difficult and failed intubation rates as compared with the general surgical population ${ }^{2-4}$. Additionally, most of the CS procedures are performed in emergency settings due to fetal distress and maternal emergencies. This risk is further complicated with the nonfasted state of the parturient. Inadequate and incompetent human resources, lack of proper technical support, and poor preoperative evaluation of airway may lead to life threatening maternal and fetal complications when the airway management fails to provide adequate oxygenation ${ }^{1,6}$. All these risk factors associated with obstetric general anesthesia have governed practitioners to perform regional techniques (spinal, epidural or combined spinal-epidural anesthesia) more frequently in CS. In the United Kingdom, general anesthesia for CS has fallen from $50 \%$ to $5 \%{ }^{3}$. On the other hand, performing regional anesthesia does not provide complete resolution of the difficult airway problem in this group of patients. Difficulties 
or contraindications to perform regional anesthesia, regional anesthesia related complications (e.g., total spinal anesthesia, local anesthetic toxicity), or real emergency situations that do not allow performing regional techniques (e.g., cardiac arrest, hemorrhage, severe fetal distress) may require general anesthesia for CS. However, regional anesthesia is still a good choice for patients with anticipated difficult airway. In addition to patients who have difficult airway prior to pregnancy, airway changes due to gaining weight and airway edema, increased breast size, uterine enlargement, decreased functional residual capacity (FRC) and increased metabolic requirements of pregnant women make airway manipulation complex and require specific skills, appropriate evaluation and systematic approach ${ }^{2-6}$. The predisposing factors leading to difficult airway should be always kept in mind by anesthesiologists and proper preparation and evaluation should be done. Pregnancy related anatomic and physiologic factors influence the anesthetists' choices and preferences for airway management.

In this review, the anatomic and physiologic changes related to pregnancy regarding airway management, the options available to anesthesiologist to manage difficult airway in pregnancy, and technical background for the management of difficult airway will be discussed.

\section{Anatomic and Physiologic Changes during Pregnancy}

There are numerous anatomic and physiologic changes during pregnancy which may affect airway management. As time advances during pregnancy, almost all changes occur for undesirable difficult airway and intubation. Excessive weight gain, upper airway edema due to increased levels of progesterone, and increased breast size can make airway manipulation troublesome. Also, decreased FRC resulting from uterine enlargement and cephalad displacement of diaphragm, and increased metabolic oxygen consumption render these women less tolerant of apnea. Furthermore, gastrointestinal tract changes to adapt to pregnancy and mostly having full stomach make them prone to aspiration ${ }^{2-10}$.

Upper airway edema due to capillary engorgement through respiratory tract results in difficulties in airway instrumentation and fiber optic intubation, and increases the risk and severity of airway bleeding, which negatively contributes to difficult airway management ${ }^{6}$. Total body water increases in pregnancy due to the increased levels of progesterone. Nasal edema makes it extremely difficult for comfortable nasal breathing. Laryngeal edema may inhibit the passage of matched size of endotracheal tube, even though laryngeal visualization is decent. Moreover, additional upper airway infections and eclampsia increase the severity of edema and deteriorate laryngeal view ${ }^{9}$.

Pregnant parturient may gain $20 \mathrm{~kg}$ or more by the end of third trimester. Obstetric literature indicates that term patients with high body mass index (BMI) are at an increased risk of undergoing CS and difficult intubation ${ }^{8,10}$. Enlargement of the uterus, cephalad displacement of the diaphragm and increased BMI lead to FRC decrease, while increasing the susceptibility to rapid decline of $\mathrm{SpO}_{2}$ in case of hypoventilation or inability to ventilate. Moreover, breast enlargement leads to difficulties in mask ventilation, positioning and insertion of the laryngoscope; using short handled laryngoscopes may be useful in overcoming this problem. Positioning of the patient to the sniffing position may help in mask ventilation and increase the quality of laryngeal visualization on direct laryngoscopy.

The progesterone mediated smooth muscle relaxation of the gastrointestinal tract, changes of stomach placement due to gravid uterus, delayed gastric emptying, and decreased tone of the upper esophageal sphincter increase the risk and incidence of silent regurgitation, vomiting and aspiration of gastric contents ${ }^{6}$.

In patients with preeclampsia and eclampsia, reduced plasma proteins due to proteinuria and marked fluid retention make the tongue larger and less mobile, and the neck and head more edematous and stiff. Anesthesiologists must be alert for the risk of difficult mask ventilation, laryngeal visualization and intubation in these patients ${ }^{11}$.

\section{Preoperative Assessment of Pregnant Patient Undergoing Cesarean Section}

Proper evaluation of the airway anatomy and airway structures is vital to prevent airway management related catastrophes. Simple airway assessment tests can easily be performed within couple of minutes, 
which will not delay the start of the case in almost all of the time. However, this evaluation may prevent the anesthesiologist from most of the unwanted surprises and provide crucial time and opportunity to ask for help and even prepare or seek appropriate equipment. In non-emergency patients with anticipated difficult airway, anesthesiologists might prefer to initiate epidural, spinal or combined spinal-epidural anesthesia, which largely prevents airway related problems and will free them from airway management.

Every anesthesiology department should prepare a difficult airway cart for rapid access. The choice of technical equipment in the difficult airway cart depends on the department resources, preferences, and spectrum of target patient population. Additionally to the basic intubation equipment, different sizes and types of supraglottic devices (LMA, I-gel, etc.), blades, laryngoscopes (McCoy, Miller, etc.), gum elastic bougie, and stylets are musts for the contents of difficult airway cart $\mathrm{t}^{12,13}$. Anesthesia providers should undergo routine and periodical training in the use of technical devices for the management of difficult airway. Fiber optic bronchoscope and video laryngoscopes are optional but very helpful for airway devices. It is highly recommended to obtain and practice at least one kind of video laryngoscope in patients with normal airway. The video laryngoscope assisted intubation is a recommended technique in the difficult airway algorithm of the American Society of Anesthesiologists ${ }^{12}$.

The anesthesiologist should include assessment of mouth opening, Mallampati class, thyromental distance, atlanto-occipital extension, and upper lip bite test for prediction of difficult airway. All these tests have been described to predict difficult airway but none of them has more than moderate sensitivity ${ }^{14-18}$. Combining bedside tests may improve predicting difficult airway but still approximately $50 \%$ of patients with difficult airway cannot be recognized ${ }^{18}$. Therefore, having a plan for unanticipated difficult airway is essential.

There is a limited relationship between the Mallampati score and laryngeal visualization grade during direct laryngoscopy. Mallampati I and II class patients are more likely to have laryngoscopic view grade I and II. However, the odds ratio for difficult intubation for Mallampati III or IV scores is 5.89 (95\% confidence interval (CI), 4.74-7.32) ${ }^{18}$. The Mallampati classifica- tion has been shown to change during pregnancy and to advance by one or two classes due to changes in pregnancy ${ }^{19}$.

It is obvious that none of the tests mentioned above is specific for prediction of difficult airway. So, the tests should be combined and careful assessment of each individual patient should be performed by the anesthesiology team.

\section{Management of Difficult Airway in Obstetrics}

1. The incidence of difficult airway, failed and fatal failed intubation is higher in obstetric patients compared to non-obstetric patients ${ }^{1-3,7,10,12,13}$. In addition to baseline difficult airway reasons, factors related to pregnancy increase the risk of difficult airway. Anesthesiologist should prefer a regional technique when it is feasible.

2. Preferring regional technique does not mean that you will not face difficult airway (e.g., failure of block, high level block, local anesthetic toxicity, cardiac arrest). Therefore, each pregnant woman must be evaluated for difficult airway with history and a combination of airway tests.

4. Despite airway evaluation, approximately $50 \%$ of unanticipated difficult airway cases remain undetectable. Anesthesiologist must have a plan for anticipated and unanticipated difficult airway scenarios ${ }^{12,13}$. Basic intubation-airway equipment including different sizes of endotracheal tubes, different types and sizes of laryngoscopes, styles, and supraglottic airway devices must be ready to use in each operating room and also where regional anesthesia is performed. Difficult intubation equipment must be ready to use and kept in a central location with an easy transport cart. Flexible fiber optic bronchoscopes, video laryngoscopes, second generation supraglottic airway devices (laryngeal masks with gastric channel, LMA proseal, supreme or I-gel may have advantage in parturients), cricothyrotomy kit and jet ventilation apparatus must be included according to department facilities and experience of practitioners. Rapid sequence intubation is standard during pregnancy due to the increased risk of aspiration. Before induction, every pregnant patient should receive $100 \%$ oxygen for at least 3-5 minutes for preoxygenation and de- 
nitrogenation ${ }^{4-7,10,12,13}$. Also, optimum positioning and aspiration prophylaxis should be used in each patient.

5. Manipulation of the airway should be minimal to avoid bleeding and upper airway trauma. Smaller endotracheal tubes should be preferred and patient should be positioned in sniffing position with the large breasts taped to avoid blockade of the neck area.

6. Awake fiber optic intubation is the first line choice in patients with anticipated difficult airway who are not candidates for regional anesthesia if it is available and the anesthesia provider is competent to use it. However, fiber optic intubation is not an option in failed intubation and poor laryngeal view when anesthesia has already been induced. Oral route is the first line choice as the edematous nasal passage may lead to excessive bleeding. Video laryngoscopes and second generation laryngeal masks with gastric channel may be better options in these scenarios. In a parturient with unanticipated difficult airway and intubation, mask ventilation must be performed to ensure oxygenation and ventilation. Applying cricoid pressure during face mask placement is controversial. Its protecting effect for aspiration is not very effective and may complicate mask ventilation. The use of oropharyngeal airway may improve mask ventilation. Emergency assistance must be asked by another anesthesiologist and maternal versus fetal status must be evaluated together with obstetrician.

7. In a parturient with unanticipated difficult airway and intubation, LMA or other types of supraglottic devices are always perfect options in case when intubation is difficult or impossible. LMA proseal provides a suction-decompression canal for the esophagus, which provides extra features to avoid aspiration of gastric contents. Intubating LMA supports intubation while providing sufficient ventilation features.

8. In case of poor laryngeal visualization, attempts with direct laryngoscopy should be limited to up to three attempts to prevent airway trauma. Bleeding of the airway may cause very limited view for video laryngoscopes and other alternative devices. Video laryngoscopes provide better laryngeal view in patients with anteriorly located glottis. The
Cormack Lehane score is decreased by at least 1 to 2 grades with the aid of video laryngoscopes compared to direct laryngoscopes. Video laryngoscopy provides a preferable option to the anesthesiologist in difficult visualization of the glottis but it requires a learning curve for successful intubation. Anesthesiologists should gain competence in using video laryngoscopes on normal airway and prepare themselves for difficult airway management.

\section{Conclusion}

Airway management in pregnant patients includes many challenges that the anesthesiologist should overcome because it involves simultaneous care of both the mother and the baby. Proper preparation and evaluation of the patient are key points of successful airway management.

The incidence of difficult airway, failed and $\mathrm{fa}-$ tal failed intubation is higher in obstetric patients as compared to non-obstetric patients. In addition to baseline difficult airway reasons, factors related with pregnancy increase the risk of difficult airway. Failure to appropriately manage difficult airway increases the risk of hypoxemic cardiopulmonary arrest and/or pulmonary aspiration, resulting in a high probability of maternal and fetal morbidity and mortality.

Proper evaluation of the airway anatomy and airway structures is vital to prevent airway management related catastrophes. Difficult intubation equipment cart must include fiber optic laryngoscope, video laryngoscopes, and different types of laryngeal masks. It is essential that all anesthesiologists must have a preconceived and well thought-out algorithm and emergency airway equipment to deal with airway emergencies during difficult or failed intubation of a parturient.

\section{References}

1. Hawkins JL, Koonin LM, Palmer SK, Gibbs CP. Anesthesia-related deaths during obstetric delivery in the United States, 1979-1990. Anesthesiology. 1997;86:277-84.

2. McKeen DM, George RB, O'Connell CM, Allen VM, Yazer $\mathrm{M}$, Wilson $\mathrm{M}$, et al. Difficult and failed intubation: incident rates and maternal, obstetrical, and anesthetic predictors. Can J Anaesth. 2011;58(6):514-24. doi: 10.1007/s12630-0119491-9.

3. Djabatey EA, Barclay PM. Difficult and failed intubation in 3430 obstetric general anaesthetics. Anaesthe- 
sia. 2009;64(11):1168-71. doi: 10.1111/j.1365-2044.2009. 06060.x.

4. Kuczkowski KM, Reisner LS, Benumof JL. Airway problems and new solutions for the obstetric patient. J Clin Anesth. 2003;15:552-63.

5. Soens MA, Birnbach DJ, Ranasinghe JS, et al. Obstetric anesthesia for the obese and morbidly obese patient: an ounce of prevention is worth more than a pound of treatment. Acta Anesthesiol Scand. 2008;52:6-19. doi: 10.1111/j.13996576.2007.01483.x.

6. Munnur U, Boisblanc BD, Suresh MS. Airway problems in pregnancy. Crit Care Med. 2005;33:259-68.

7. Mhyre JM, Healy D. The unanticipated difficult intubation in obstetrics. Anesth Analg. 2011;112:648-52. doi: 10.1213/ ANE.0b013e31820a91a6.

8. Rao DP, Rao VA. Morbidly obese parturient: challenges for the anaesthesiologist, including managing the difficult airway in obstetric. What is new? Indian J Anaesth. 2010;54:508-21. doi: 10.4103/0019-5049.72639.

9. Brimacombe J. Acute pharyngolarnyngeal oedema and preeclamptic toxaemia. Anaesth Intensive Care. 1992;20:97-8.

10. Ezri T, Szmuk P, Evron S, et al. Difficult airway in obstetric anesthesia: a review. Obstet Gynecol Surv. 2001;56:631-41.

11. Ramanathan J, Bennett K. Pre-eclampsia: fluids, drugs, and anesthetic management. Anesthesiol Clin North Am. 2003;21:145-63.

12. Apfelbaum JL, Hagberg CA, Caplan RA, Blitt CD, Connis RT, Nickinovich DG, et al. American Society of Anesthesiologists Task Force on Management of the Difficult Airway. Practice guidelines for management of the difficult airway: an updated report by the American Society of Anesthesiologists Task Force on Management of the Difficult
Airway. Anesthesiology. 2013;118(2):251-70. doi: 10.1097/ ALN.0b013e31827773b2.

13. American Society of Anesthesiologists Task Force on Obstetric Anesthesia. Practice guidelines for obstetric anesthesia: an updated report by the American Society of Anesthesiologists Task Force on Obstetric Anesthesia. Anesthesiology. 2007;106(4):843-63.

14. Basaranoglu G, Columb M, Lyons G. Failure to predict difficult tracheal intubation for emergency caesarean section. Eur J Anaesthesiol. 2010;27(11):947-9. doi: 10.1097/ EJA.0b013e32833e2656.

15. Vannucci A, Cavallone LF. Bedside predictors of difficult intubation: a systematic review. Minerva Anestesiol. 2016 Jan;82(1):69-83.

16. Ambesh SP, Singh N, Rao PB, Gupta D, Singh PK, Singh U. A combination of the modified Mallampati score, thyromental distance, anatomical abnormality, and cervical mobility (M-TAC) predicts difficult laryngoscopy better than Mallampati classification. Acta Anaesthesiol Taiwan. 2013;51(2):58-62. doi: 10.1016/j.aat.2013.06.005.

17. Baker P. Assessment before airway management. Anesthesiol Clin. 2015;33(2):257-78. doi: 10.1016/j.anclin.2015.02.001.

18. Lundstrøm LH, Vester-Andersen M, Møller AM, Charuluxananan S, L'hermite J, Wetterslev J; Danish Anaesthesia Database. Poor prognostic value of the modified Mallampati score: a meta-analysis involving 177088 patients. Br J Anaesth. 2011;107(5):659-67. doi: 10.1093/bja/aer292.

19. Boutonnet M, Faitot V, Katz A, Salomon L, Keita H. Mallampati class changes during pregnancy, labour, and after delivery: can these be predicted? Br J Anaesth. 2010;104(1):6770. doi: 10.1093/bja/aep356.

Sažetak

\section{IZAZOVI OPSTETRICIJSKE ANESTEZIJE: OTEŽANA VIZUALIZACIJA LARINKSA}

\section{Z. Alanoğlu, S.K. Erkoş, C.Y. Güçlü, B.C.O. Meço, V. Baytaş, Ö.S. Can i N.Alkı̧̧}

Opstetricijska anestezija je visokorizična anesteziološka supspecijalnost. Komplikacije vezane uz anesteziju su šesti vodeći uzrok majčine smrtnosti. Otežana ili nemoguća intubacija nakon uvoda u opću anesteziju je glavni čimbenik koji doprinosi komplikacijama vezanim uz anesteziju rodilja. Zbrinjavanje dišnoga puta u rodilja je izazov iz više razloga. Anatomske i fiziološke promjene u trudnoći povećavaju učestalost otežane i nemoguće intubacije u odnosu na opću kiruršku populaciju. Zadovoljavajuća evaluacija anatomije dišnoga puta i dišnih struktura je životno važna da bi se spriječile katastrofe vezane uz zbrinjavanje dišnoga puta. Uz osnovnu opremu za dišni put i intubaciju svaki anesteziološki odjel mora imati kolica s opremom za otežani dišni put koja uključuju fiberoptički laringoskop, videolaringoskop i različite vrste laringealnih maski. Nužno je da svi anesteziolozi imaju unaprijed osmišljene i dobro razrađene algoritme i opremu za hitno zbrinjavanje dišnoga puta kako bi postupali s hitnoćama dišnoga puta u otežanoj ili nemogućoj intubaciji rodilja.

Ključne riječi: Anestezija, opía; Anestezija, opstetricijska; Dišni put, zbrinjavanje; Intubacija, intratrahealna; Dišni put, opstrukcija 